\section{Response to Gomy and Garber}

The American College of Medical Genetics and Genomics (ACMG) appreciates the continuing debate about genomic screening by way of the opportunistic screening and reporting of pathogenic variations in secondary findings genes in asymptomatic individuals and the opportunity to respond to the letter from Gomy et al. ${ }^{1}$ that comments on our secondary findings recommendations. ${ }^{2-6}$ We stand by our prior statements that secondary findings for a subset of cardiovascular, cancer, and other genes with evidence of medical actionability offer the opportunity to provide potentially useful information to individuals having their genomes sequenced for clinical indications. This data can provide the evidence needed to inform the questions of clinical utility of broad genomic screening in unselected populations.

\section{DISCLOSURE}

The Board of Directors of the ACMG declares no conflicts of interest.

Publisher's note Springer Nature remains neutral with regard to jurisdictional claims in published maps and institutional affiliations.

\author{
American College of Medical Genetics and Genomics' Board of \\ Directors \\ Correspondence: documents@acmg.net
}

\section{REFERENCES}

1. Gomy I, Garber J. Response to the ACMG secondary findings recommendations for general population screening: a policy statement of the American College of Medical Genetics and Genomics (ACMG). Genet Med (in press).

2. ACMG Board of Directors. The use of secondary findings recommendations for general population screening: a policy statement of the American College of Medical Genetics (ACMG). Genet Med. 2019:21:1467-1468.

3. American College of Medical Genetics and Genomics. ACMG releases clarification statement on "The use of ACMG secondary findings recommendations for general population screening." https://www. acmg.net/PDFLibrary/Clarification Released -should Secondary Findings in Genetics Be Used for General Population Screening.pdf. Accessed May 2019.

4. ACMG Board of Directors. ACMG response to Nussbaum et al. letter on ACMG policy statement: the use of secondary findings recommendations for general population screening: a policy statement of the ACMG. Genet Med. 2019 Jun 26; https://doi.org/10.1038/s41436-019-0573-3 [Epub ahead of print].

5. Green RC, Berg JS, Grody WW, et al. ACMG recommendations of incidental findings in clinical exome and genome sequencing. Genet Med. 2013;15:565-574.

6. Kalia SS, Adelman K, Bale SJ, et al. Recommendations for reporting of secondary findings in clinical exome and genome sequencing, 2016 update. Genet Med. 2017;19:249-255.

Advance online publication 3 October 2019. doi:10.1038/s41436-019-0661-4 